\title{
Dactylamblyops corberai n. sp., a new mysid (Crustacea: Mysida) from the deep Mediterranean Sea
}

\author{
CARLOS SAN VICENTE ${ }^{1}$ and JOAN E. CARTES ${ }^{2}$ \\ ${ }^{1}$ C/ Nou, 8. 43839 Creixell. Tarragona, Spain. E-mail: csanvicente@gencat.cat \\ 2 Institut de Ciències del Mar (ICM-CSIC), Passeig Marítim de la Barceloneta, 37-49, E-08003 Barcelona, Spain. \\ E-mail: jcartes@icm.csic.es
}

\begin{abstract}
SUMMARY: A new Erythropinae mysid, Dactylamblyops corberai n. sp., is described from specimens sampled with a $500-\mu \mathrm{m}$ plankton net attached to a bottom trawl in the Ionian Sea (eastern Mediterranean). This new species is the first Dactylamblyops species described from the Mediterranean Sea. Based on a revision of additional material from several cruises made in recent years, we conclude that $D$. corberai is a widespread species in the deep Mediterranean near-bottom suprabenthic community at depths between 398 and $1859 \mathrm{~m}$. The main distinguishing features of D. corberai are the shape of the eyes and their ocular process, and the shape of the labrum with two rows of clusters of short setules and two areas covered with small, scale-like protrusions not described in any other species of the genus. $D$. corberai belongs to the morphological hodgsoni group of Dactylamblyops species.
\end{abstract}

Keywords: Mysida, Mysidae, endemism, Mediterranean Sea, deep sea.

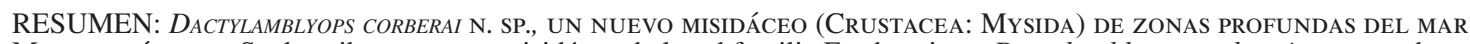
MEdITERRÁNEO. - Se describe un nuevo misidáceo de la subfamilia Erythropinae, Dactylamblyops corberai n. sp., en base a diversos ejemplares muestreados en el mar Jónico (Mediterráneo Oriental) con una red de plancton de $500 \mu \mathrm{m}$ adosada a una red de arrastre comercial. Esta nueva especie es la primera del género Dactylamblyops descrita en el mar Mediterráneo. El estudio de diverso material adicional recolectado en diferentes campañas de muestreo permite concluir que $D$. corberai presenta una amplia distribución en el nivel suprabentónico de las zonas profundas del Mediterráneo, entre profundidades de 398 a $1859 \mathrm{~m}$. Las principales características morfológicas de $D$. corberai son la forma de los ojos y de la protuberancia ocular, así como la forma peculiar del labrum con dos filas de pequeñas sétulas y dos áreas cubiertas con salientes en forma de escamas. D. corberai pertenece al grupo morfológico de especies tipo hodgsoni del género Dactylamblyops.

Palabras clave: Mysida, Mysidae, endemismo, mar Mediterráneo, zonas profundas.

\section{INTRODUCTION}

The mysid fauna of the Mediterranean Sea is considered one of the best known (Mauchline, 1980; Wittmann, 1999). However, the Mediterranean mysid inventory is far from being completed (Wittmann, 2001). The temporal trend in the description of new species indicates an incompletely documented fauna and suggests that there are still a number of undescribed species in this Sea (San Vicente, 2010). In deep sea domains (depths below $200 \mathrm{~m}$ ) Mediterranean habitats still remain far from being reasonably explored, in spite of the increasing effort devoted to the study of their peracarid fauna since the 1990s (Cartes and Sorbe, 1995; Cartes et al., 2001; 2003). This coincided with the use of suprabenthic sledges (Cartes et al., 1994) to sample the deep sea sediment-water interface. Some new species were described in the Balearic Basin (Ruffo et al., 1999; Jaume et al., 2000). Mysids, having the highest natatory capacity among peracarids, are well sampled preferably using suprabenthic sledges. Based on quantitative samplings mysids are the dominant taxa in terms of biomass, though they are the lowest diversified among peracarids in the deep Mediterra- 
nean (Cartes and Sorbe, 1995, Cartes et al., 2003). In this area, particular emphasis has been placed on the characterization of deep assemblages of peracarids and their ecological importance as trophic resources for fish and large invertebrates.

The genus Dactylamblyops was established by Holt and Tattersall (1906) after the reception of an Antarctic species collected by the $\mathrm{R} / \mathrm{V}$ Discovery. In the same study, these authors also transferred Amblyops sarsi Ohlin (1901) sampled from Spitzbergen to this genus on the strength of Ohlin's description and figures.

To date, 14 species of Dactylamblyops are known (Anderson, 2010): D. sarsi (Ohlin, 1901), D. hodgsoni Holt and Tattersall, 1906, D. latisquamosa Illig, 1906, D. goniops Tattersall, 1907, D. thaumatops Tattersall, 1907, D. fervida Hansen, 1910, D. murrayi Tattersall, 1939, D. laticauda Birstein and Tchindonova, 1958, D. pellucida Birstein and Tchindonova, 1958, D. solivaga Birstein and Tchindonova, 1958, D. tenella Birstein and Tchindonova, 1958, D. stenurus Murano, 1969, D. iii Nouvel and Lagardère, 1976 and D. atlanticus $\mathrm{Mu}-$ rano and Mauchline, 1999. The genus Dactylamblyops is widely distributed throughout the world oceans, from the Arctic to the Southern Ocean, including the Atlantic, the Pacific and the Indian Ocean. The species of Dactylamblyops are generally deep-water mysids inhabiting both the bathypelagic and the suprabenthic zone; they are rarely recorded and always represented by a low number of specimens. During a series of bottom trawls performed in the Ionian Sea in 1999-2000, unidentified Dactylamblyops specimens were sampled with a 500- $\mu \mathrm{m}$ mesh-size plankton net attached to a commercial bottom trawl. A detailed morphological study of these specimens revealed that they actually belonged to a species new to science.

This paper deals with the description of the new species Dactylamblyops corberai. The description of this taxon constitutes a good example of how relatively abundant species in the deep Mediterranean can still remain unknown to science. We will emphasize that $D$. corberai is widely distributed in both the western (Cartes and Sorbe, 1995, Cartes et al., 2003) and the eastern (Madurell and Cartes, 2003) basins, where it was cited as Dactylamblyops sp. or Dactylamblyops sp. A.

\section{MATERIALS AND METHODS}

The specimens studied herein were collected during a series of bottom trawls performed in the Ionian Sea (between the west coast of the Peloponese and the island of Zakinthos) in 1999-2000. They were caught with a $500-\mu \mathrm{m}$ plankton net $\left(0.16 \mathrm{~m}^{2}\right.$ frame-shaped mouth aperture) attached to the upper part of a commercial bottom trawl. The animals appeared in good state compared to material collected with suprabenthic sledges, so they were chosen as holotypes/paratypes for the current description. The specific composition of peracarid Crustacea (suprabenthos) by sampling station of all these trawls is available at Madurell and Cartes (2003).
Other specimens of Dactylamblyops corberai n. sp. cited previously as Dactylamblyops sp. (Cartes and Sorbe, 1995) or Dactylamblyops sp. A (Cartes et al., 2003; Madurell and Cartes, 2003) were also collected in different areas of the western Mediterranean using a Macer-GIROQ suprabenthic sledge (see below). Also, one specimen was collected in the water column with a 500- $\mu \mathrm{m}$ mesh size WP2 plankton net equipped with a General Oceanics opening-closing system (Table 1).

Samples were preserved in a solution of $10 \%$ buffered formaldehyde. Specimens were counted and measured under a dissecting microscope with an eyepiece micrometer. Whenever possible the individual size was determined from the measurement of the carapace length (CL: measured from the apex of the rostrum to the posterior dorsal edge of the carapace) and/ or the total length (TL: from the apex of the rostrum to the posterior end of the telson, excluding spines) to the nearest $0.1 \mathrm{~mm}$. Specimens selected for the species description were dissected and temporarily mounted on slides. Dissected appendages were drawn with the aid of a camera lucida mounted on a Zeiss Axioscop 20 microscope. Type material is deposited at the Institut de Ciències del Mar (ICM) of Barcelona, Spain. Description below refers to both sexes, unless otherwise stated.

\section{RESULTS}

\section{Systematics}

\author{
Order Mysida Haworth, 1825 \\ Family MYSIDAE Haworth 1825 \\ Subfamily ERYTHROPINAE Hansen, 1910 \\ Genus Dactylamblyops Holt and Tattersall, 1906 \\ Dactylamblyops corberai n. sp.
}

$$
\text { (Figs. 1-4) }
$$

Material examined. Holotype: (ICMM 1/2010) Mature male, $7.7 \mathrm{~mm}$ TL; St T02N3, 27/02/2000; Ionian Sea, $37^{\circ} 47.67^{\top} \mathrm{N}$; $21^{\circ} 03.33^{\prime} \mathrm{E} ; 585 \mathrm{~m}$ depth; muddy bottoms; $\mathrm{T}=14.1^{\circ} \mathrm{C} ; \mathrm{S}=38.61$ (from CTD casts performed simultaneously to net sampling). Paratypes: (ICMM 2/2010) One mature male (7.0 mm TL; St T02N1, 26/02/2000, Ionian Sea, 37 $48.14^{\prime} \mathrm{N}$; $21^{\circ} 03.29^{\prime} \mathrm{E}, 594 \mathrm{~m}$ depth); eight mature males (two males each of 7.0, 7.1, 7.2 and 7.4 mm TL; St T02N2; 26/02/2000; Ionian Sea, 37 $50.90^{\prime} \mathrm{N} ; 21^{\circ} 56.87^{\prime} \mathrm{E} ; 510 \mathrm{~m}$ depth); two mature males (6.8 and $7.6 \mathrm{~mm}$ TL, same locality as holotype).

Other specimens were collected in other geographic locations of the deep Mediterranean (Table 1).

Diagnosis. Eyes large with long finger-like process on dorsomedial surface; process reaching distal end of cornea. Labrum with double row of short setae and covered with small, scale-like outgrowths. Three setae on inner ventral margin of endopod of uropod close to statocyst. Single median slender seta at apex of telson.

Description. Carapace produced anteriorly into small rounded rostrum with blunt tip extending to base of eyestalks (Figs. 1A-B); antero-lateral angles 

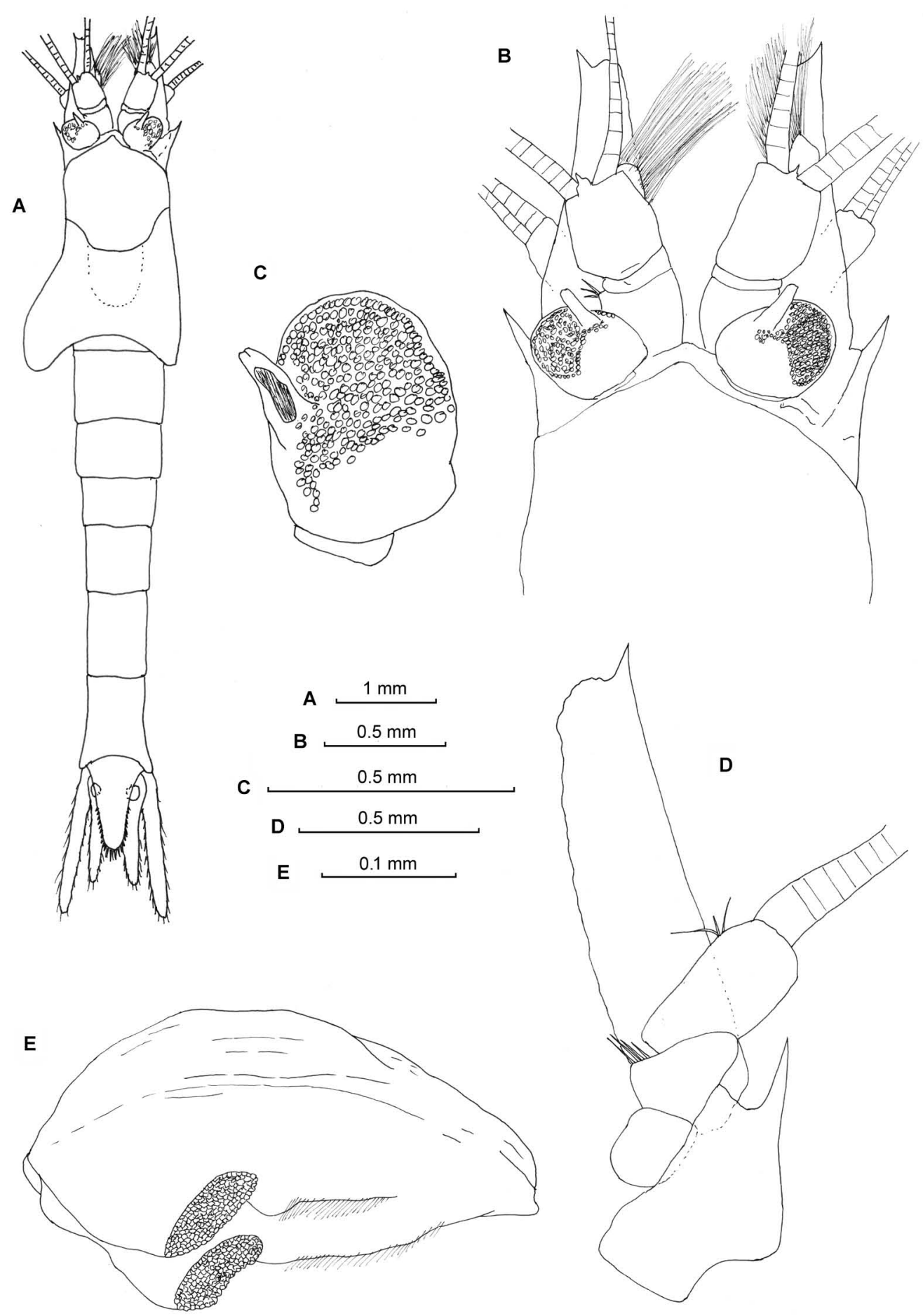

FIG. 1. - Dactylamblyops corberai $\mathrm{n}$. sp.; holotype, mature male: A, habitus in dorsal view; B, anterior portion in dorsal view; C, eye; D, antenna in ventral view; E, labrum.

rounded; cervical sulcus well marked; slightly emarginate posteriorly leaving last thoracic somite partially exposed in dorsal view.

Abdomen longer than carapace; first, second and fourth segments subequal in length; third segment shorter and fifth and sixth segments longer (Fig.1A).

Eyes large and more or less quadrangular at base and oval distally; with small but definite stalks; each eye bearing long finger-like process on dorsomedial surface projecting until distal end of cornea (Fig 1C). 


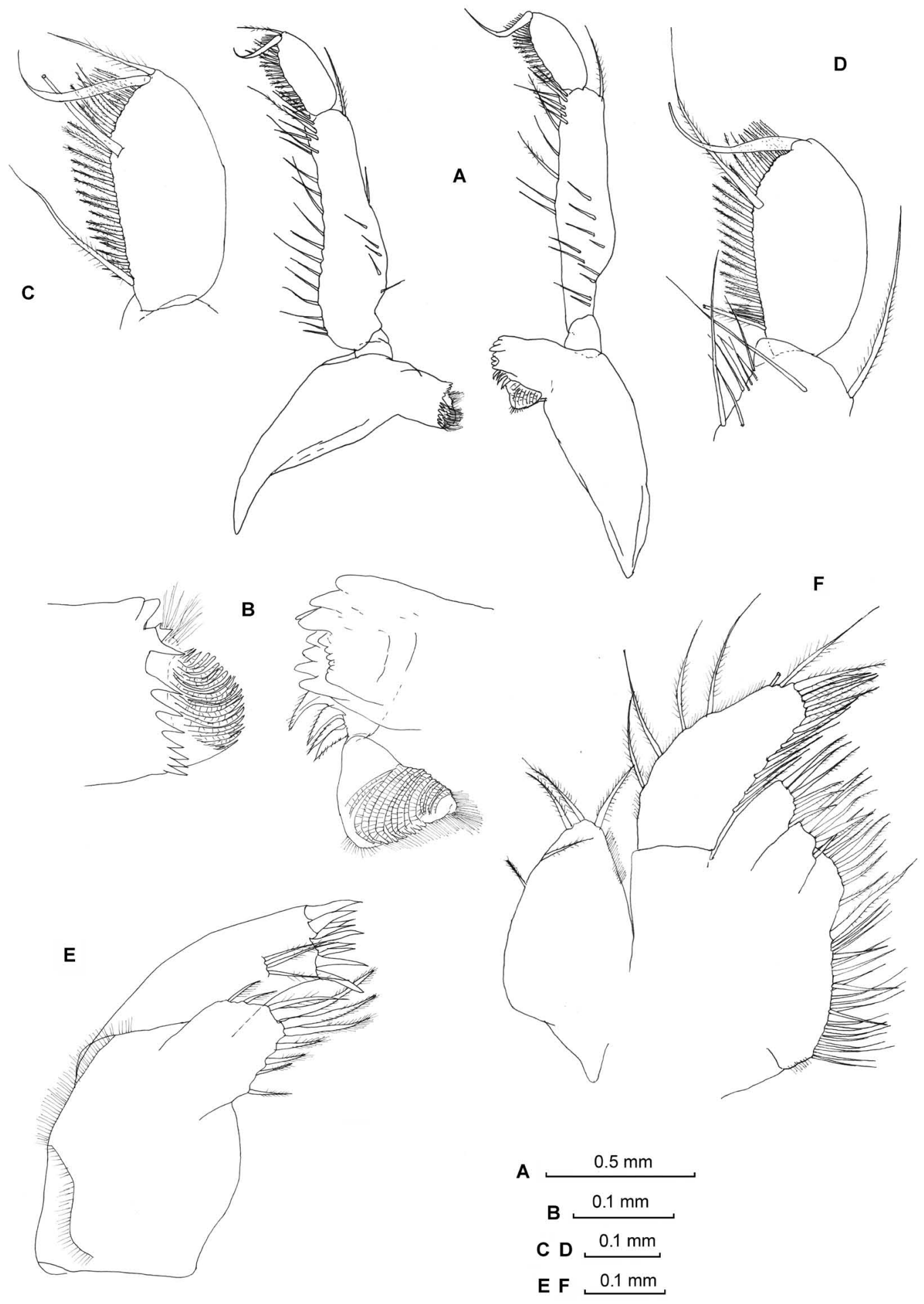

FIG. 2. - Dactylamblyops corberai $\mathrm{n}$. sp.: A, mandibles; B, cutting edges of mandibles; C, terminal segment of right mandibular palp; D, terminal segment of left mandibular palp; E, maxillule; F, maxilla. A-E, holotype, mature male; F, paratype, mature male TL 7.0 mm.

Antennular peduncle extending to about midway of antennal scale, third segment longest, second segment very short; outer distal margin of first segment furnished with three short setae (Fig. 1B).
Antennal peduncle short, 3-segmented, about half as long as scale, not extending beyond antennular peduncle; third segment longest, overlapping second segment; inner distal margin of second and third segments 

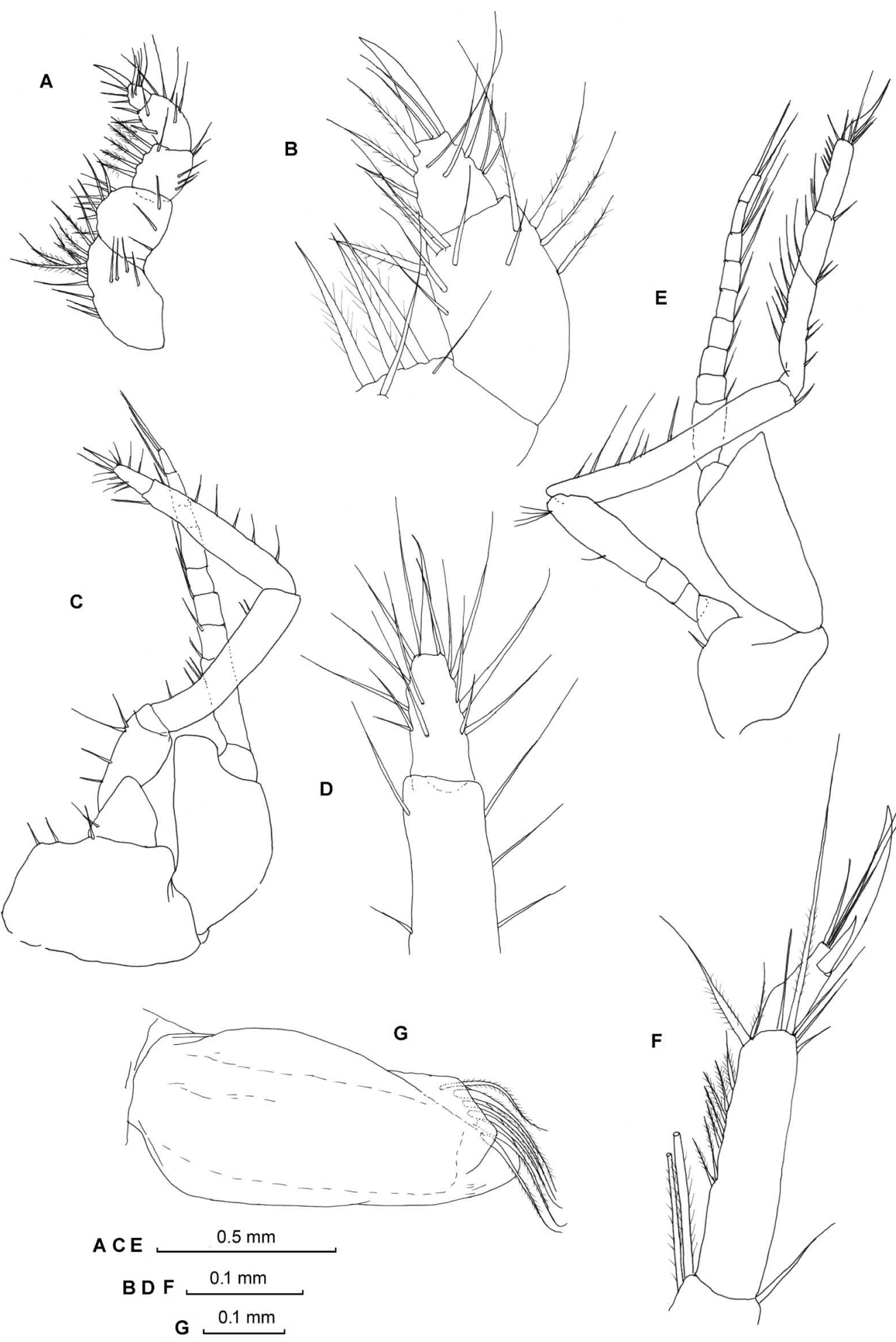

G
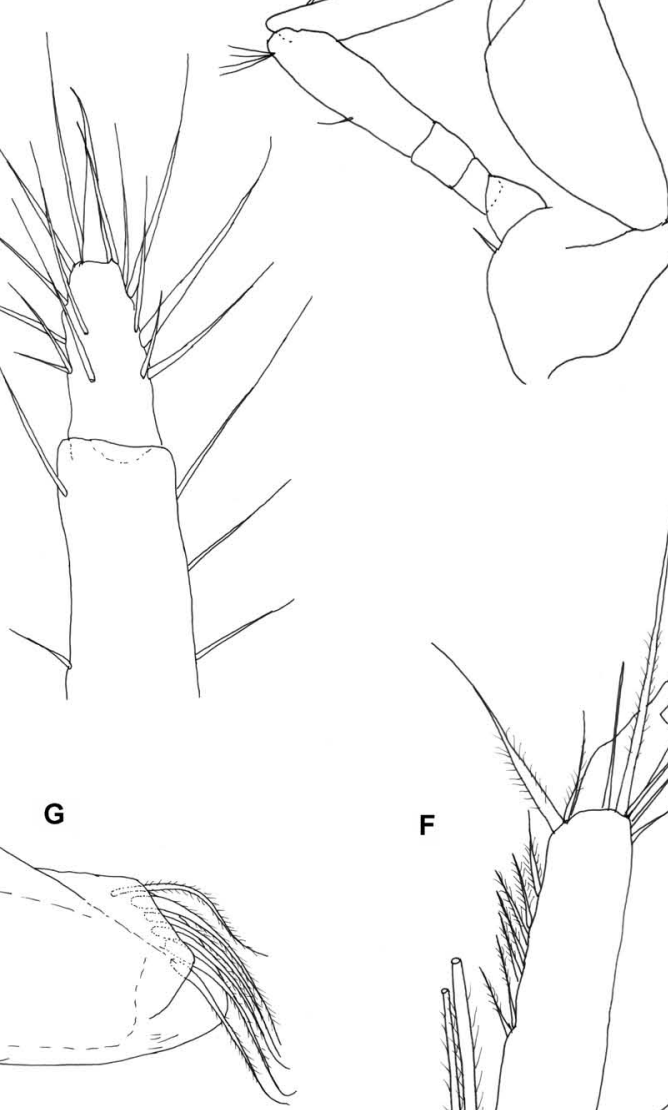

FiG. 3. - Dactylamblyops corberai n. sp.: A, endopod of 1st thoracopod; B, chela of 1st endopod thoracopod; C, 2nd thoracopod; D, chela of 2nd thoracopod endopod; E, 7th thoracopod; F, chela of 7th thoracopod; G, male genital organ; A-D, holotype, mature male; E-G, paratype, mature male TL $7.0 \mathrm{~mm}$.

with four and three setae, respectively. Protopod of antenna relatively slender, with outer distal angle produced into strong spine (Fig 1D). Antennal scale long and slender, nearly four times as long as maximum width; extending for more than one third of its length beyond antennular peduncle; lateral margin naked; terminating in a strong spine extending clearly beyond apex of scale; distal suture absent. 

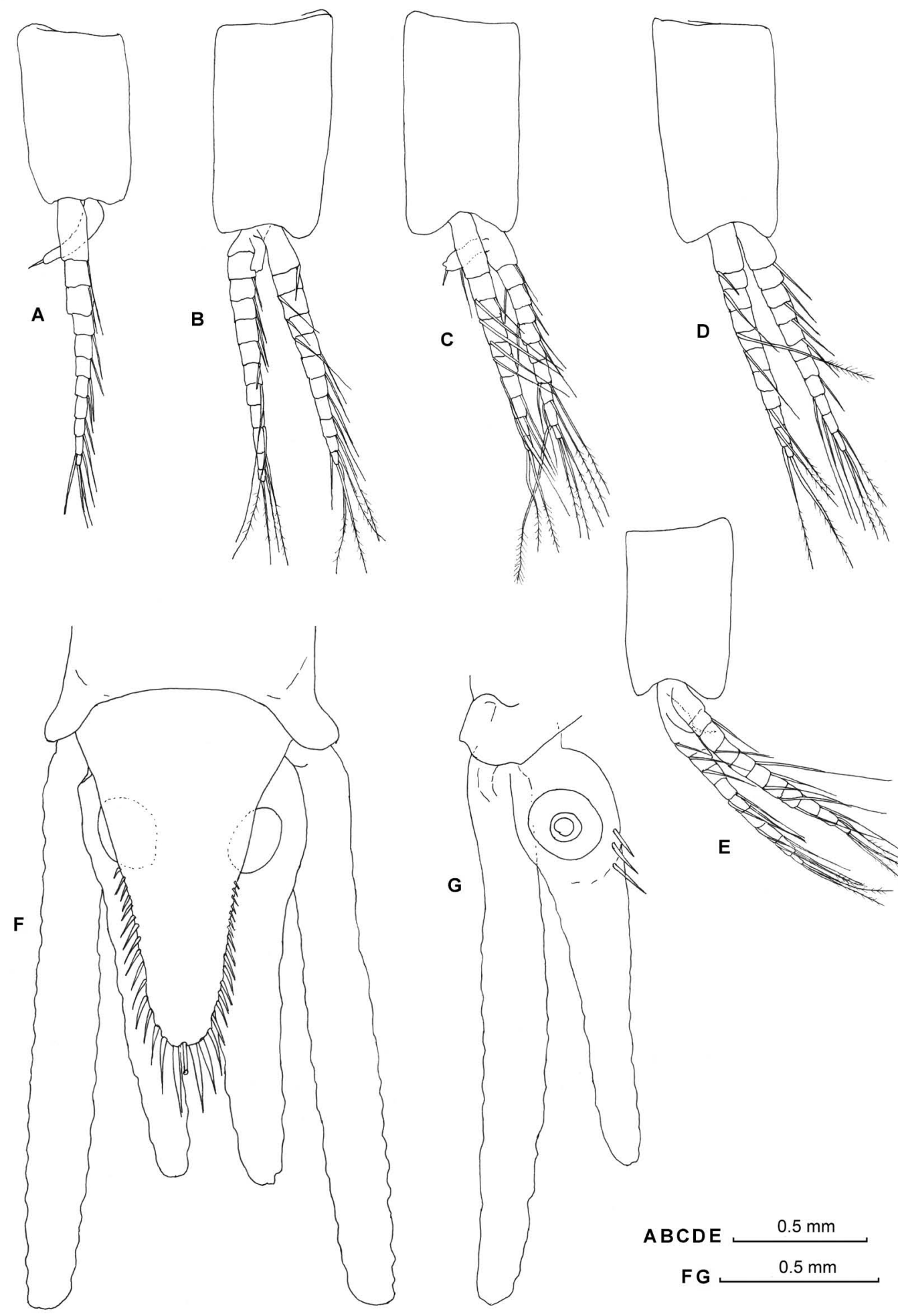

FIG. 4. - Dactylamblyops corberai $\mathrm{n}$. sp.; holotype, mature male: A, 1st pleopod; B, 2nd pleopod; C, 3rd pleopod; D, 4th pleopod; E, 5th pleopod; F, uropods and telson in dorsal view; G, uropod in ventral view.

Labrum (Fig. 1E) almost triangular; posterior surface with two distinct areas each comprising a row (or patch) of short setules plus a patch of tightly-set, small, scale-like integumentary outgrowths.
Mandibles (Fig. 2A) with palp large and slender, 3 -jointed, first segment shortest, second segment more than twice long than the third one. Left mandible with well developed incisor and molar process, plus row of 
four hirsute spines; counterpart on right mandible comprising eight entire spines (Fig. 2B). Distal segment of palp (Figs. 2C-D) with enlarged proximo-ventral seta and two distoventral setae; medial margin with row of 20 pinnate setae and distal row of seven to eight shorter pinnate setae; one long pinnate seta on tip of segment (not shown in Fig. 2D); dorsal margin unarmed.

Maxillule (Fig. 2E) basal endite (outer lobe) apex armed with nine cuspidate setae and three long setae on ventral surface; coxal endite (inner lobe) with ten plumose setae, of which three apical larger; proximal anterior margin of coxa with row of setules.

Maxilla (Fig. 2F) with endopod twice as long as wide, densely setose on inner margin; outer margin with five plumose setae and row of setules; protopodal endites armed with plumose setae on inner margins; exopod large, with five plumose setae on outer margin and row of setules on inner margin.

First and second thoracic appendages formed as maxillipeds. First thoracopod small and robust, biramous; endopod dactylus short, half as long as propodus, with three spinose setae on inner margin and robust distal nail; propodus bearing three pappose setae on inner margin; merus with five pappose setae on inner margin; ischium with nine setae on inner margin; preischium with six pappose setae on inner distal margin (Figs. 3A-B).

Endopod of second thoracopod with preischium shorter than ischium, inner margin armed with simple seta; ischium with four setae on inner margin; merus and carpo-propodus longest, subequal in length; dactylus short armed with fifteen setae and distal nail; exopod nine-articulated (Figs. 3C-D).

Third to sixth and eighth thoracic appendages broken in all individuals examined. Endopod of seventh thoracopod with dactylus armed with two distal nails; carpo-propodus separated into three subsegments, merus subequal in length to carpo-propodus; ischium divided into three subsegments; preischium short and unarmed; exopod 10-articulated, shorter than endopod (Figs. 3E-F). Male genital organ bearing six apical pappose setae (Fig. 3G).

Pleopods of male biramous; endopods with small side lobes (Figs. 4 A-E). First pleopod exopod 11-articulated, endopod unsegmented. Second to fifth pleopods with exopod 11-articulated exopod and 9- to 12-articulated endopod. Female pleopods uniramous, unjointed, increasing in length towards posterior end.

Uropods long and slender, extending to apex of telson (Fig. 4F-G); exopod longer than endopod; inner ventral margin of endopod armed with three setae near statocyst (Fig. 4G).

Telson subequal in length to last abdominal somite and twice as long as broad at base (Fig. 4F); linguiform in shape; distal half of lateral margins armed with 1516 setae increasing in length towards distal end; apex with two pairs of longer and larger setae; single median slender seta present at apex (broken in all individuals examined).

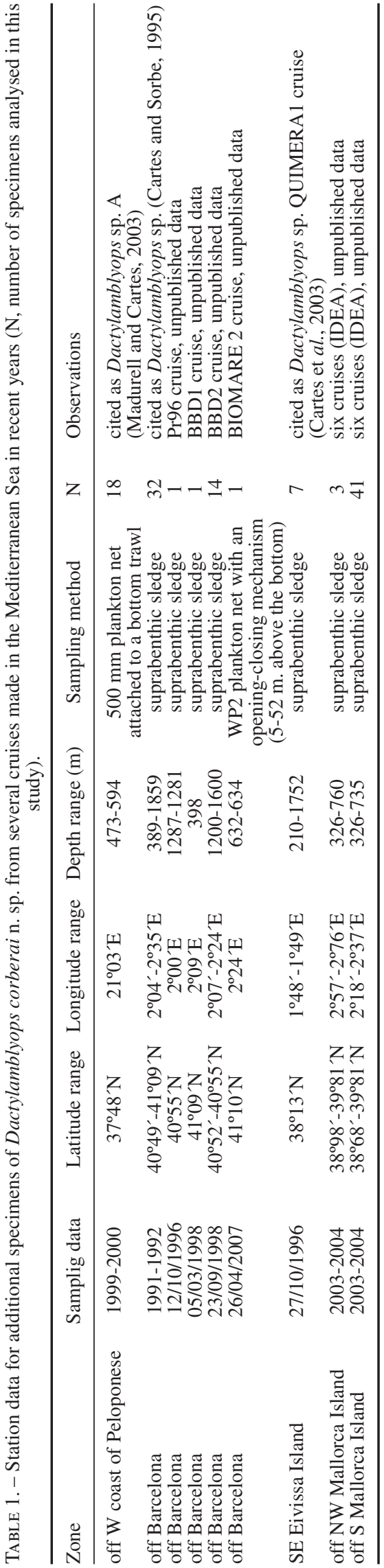


Colour in live specimens: white with some yellowish tinge.

Etymology. This species is named in honour of Mr. Jordi Corbera in recognition of his contribution to the knowledge and artistic paintings of Mediterranean fauna.

Distribution and habitat. The species distribution comprises, in addition to the type locality (Ionian Sea), the Balearic Basin (off Barcelona, NW Mallorca) and the Algerian basin close to the Balearic Islands (SW Mallorca and SW Eivissa) (Table 1).

The habitat of $D$. corberai comprises the nearbottom layer (0-2 metres above the bottom) at depths between 398 and $1858 \mathrm{~m}$ on muddy bottoms. In the Ionian Sea the species lives in the water column at $\mathrm{T}=14.0-14.8^{\circ} \mathrm{C}$ and $\mathrm{S}=38.3-38.7$. In the western Basin it is found at the deepest stations sampled $(1858 \mathrm{~m})$, though the species showed its highest abundance off Catalonian coasts at 1253-1287 m depth and to the SW of Mallorca Island at 350-650 m depth.

\section{DISCUSSION}

Species of the genus Dactylamblyops can be divided into seven morphological groups on the basis of the form of the eye: the hodgsoni group, the sarsi group, the thaumatops group, the goniops group, the tenella group, the solivaga group and the laticauda group"(Murano, 1981). Their exact systematic positions remains unresolved, and several authors have expressed doubts regarding the taxonomic validity of some species of the genus (Tattersall and Tattersall, 1951; Ii, 1964; Nouvel and Lagardère, 1976; Murano, 1981).

According to Murano (1981), the hodgsoni group is defined as follows: "eye pyriform, not flattened, with a digitate process on inner dorsal surface; cornea imperfectly developed; telson elongate linguiform or elongate triangular, armed with many spines on distal half of lateral margin and apex, without plumose setae or a tiny spine on apex". The Dactylamblyops hodgsoni group is composed of the following five species: $D$. hodgsoni from the Southern Ocean, D. fervida known only from the type locality in the Moluccas, D. latisquamosa from Indonesia (Sumatra), D. murrayi from the Arabian Sea and Japan, and D. stenurus from Japan. These species agree with the original diagnosis of the genus by Holt and Tattersall (1916) and must be considered as true members of the genus Dactylamblyops (Murano, 1981). The morphological description of D. atlanticus from Ireland (Murano and Mauchline, 1999) coincides with Murano's grouping (1981) and, consequently, this species should be added to the hodgsoni group.

D. corberai belongs to the morphological hodgsoni group of Dactylamblyops species. The main distinguishing features of $D$. corberai are the shape of the eyes and their ocular process; the peculiar shape of the labrum with a double row of clusters of short setules and two areas covered with small scale-like protrusions (not described in any other species of the genus); the presence of three setae on the inner ventral margin of the endopod in the region of the statocyst and the armature of the lateral margins of the telson. The new species can be recognized at first glance by the combination of these characters. It should be remarked that individuals of this new species are very fragile and, though we analysed a fairly large number of specimens, only in rare were cases individuals found in good condition.

This species closely resembles $D$. hodgsoni in the shape of the eye, the elongate antennal scale and the shape of the telson. D. corberai has a triangular rostrum with rounded apex while $D$. hodgsoni has a semicircular rostrum. In the new species the eye is large, with more or less quadrangular base and oval distally while in $D$. hodgsoni it is pyriform in shape. In D. hodgsoni the antennal scale is subequal in length to the antennular peduncle and the outer distal spine does not extend beyond the apex of the scale, whereas in the new species the antennal scale extends beyond the antennular peduncle, and the outer distal spine is clearly longer than the apical lobe. The number of lateral spines on the telson is lower in D. corberai (15-16) than in $D$. hodgsoni (19), whereas a median seta is present in the new species and absent in the latter species.

The new species can be distinguished from Dactylamblyops murrayi, D. stenurus and D. atlanticus on the basis of: (1) the number of setae on the inner ventral margin of the endopod of uropod (three setae in D. corberai, only one in the latter three species); (2) the relative size of the ocular process (reaching distal end of cornea; not reaching it in D. murrayi, or not extending to distal margin of eye in D. stenurus and D. atlanticus); (3) and the armature of the lateral margin of telson (armed with 15-16 setae in D. corberai, 28 in D. murrayi, 25 in D. atlanticus and 19-20 in D. stenurus). D. corberai differs from D. latisquamosa in the shape of rostrum (both display a triangular outline but, whereas the apex is rounded in the new species, it is acutely pointed in D. latisquamosa). Differences from $D$. fervida rely on the shape of the antennal scale and ocular process (shorter than the antennular peduncle and the ocular process in the new species than in D. fervida). D. corberai differs from an unassigned species from California reported by Tattersall (1951) in the shape and armature of the telson (telson quadrangular with about 26 setae in this unassigned species versus only $15-16$ setae in $D$. corberai. The two species of the genus with a distribution that falls closer to $D$. corberai, viz. D. goniops and D. thaumatops, from the Bay of Biscay (NE Atlantic) (Tattersall and Tattersall, 1951; Nouvel and Lagardere, 1976) and the Cantabrian Sea (I. Frutos, pers. comm.), do not belong to the hodgsoni group, thus clearly differing morphologically from D. corberai.

Dactylamblyops corberai $\mathrm{n}$. sp. is the first species of the genus described from the Mediterranean 
TABLE 2. - Summary of known data on geographical distribution, bathymetric range and habitat of Dactylamblyops species $\left({ }^{1}\right.$ Murano and Mauchline, 1999; ${ }^{2}$ Hansen, 1910; ${ }^{3}$ Tattersall and Tattersal, 1951; ${ }^{4}$ Nouvel and Lagardere 1976; ${ }^{5}$ Holt and Tattersall, $1906 ;{ }^{6}$ Ii, $1964 ;{ }^{7}$ Birstein and Tchindonova, 1958; ${ }^{8}$ Illig, $1906 ;{ }^{9}$ Illig, 1930; ${ }^{10}$ Ohlin, 1901; ${ }^{11}$ Murano, 1969).

\begin{tabular}{|c|c|c|c|c|c|}
\hline Species & Latitude range $\left(^{\circ}\right)$ & Distribution & Habitat & Depth range $(\mathrm{m})$ & References \\
\hline D. atlanticus Murano and Mauchline, 1999 & $54 \mathrm{~N}$ & NE-Atlantic (Ireland) & bathypelagic & 2500 & 1 \\
\hline D. fervida Hansen, 1910 & $1 \mathrm{~S}$ & Indonesia: Mollucas & mesopelagic & - & 2 \\
\hline D. goniops Tattersall, 1907 & $59 \mathrm{~N}-44 \mathrm{~N}$ & $\begin{array}{l}\text { NE-Atlantic (Ireland, } \\
\text { Faroes, Bay of Biscay) }\end{array}$ & benthic & $585-1300$ & 3,4 \\
\hline D. hodgsoni Holt and Tattersall, 1906 & $53 \mathrm{~S}-66 \mathrm{~S}$ & Southern Ocean & benthic & $500-4000$ & 5 \\
\hline D. iii Nouvel and Lagardère, 1976 & $35 \mathrm{~N}$ & Japan & bathypelagic & $?<350-1200$ & 6,4 \\
\hline D. laticauda Birstein and Tchindonova, 1958 & $49 \mathrm{~N}$ & -Pacific (Kurile-Kamtchatka). & bathypelagic & 4500 & 7 \\
\hline D. latisquamosa Illig, 1906 & $10 \mathrm{~N}-0$ & Indonesia (Sumatra) & - & 800 & 8,9 \\
\hline D. murrayi Tattersall, 1939 & $35 N-20 N$ & Arabian Sea; Japan & mesopelagic & $500-? 1200$ & 6 \\
\hline D. pellucida Birstein and Tchindonova, 1958 & $29 \mathrm{~N}$ & Japan & mesopelagic & $1000-4400$ & 7 \\
\hline D. sarsi (Ohlin, 1901) & $70 \mathrm{~N}-60 \mathrm{~N}$ & Arctica (Spitzbergen). & mesopelagic & - & 10 \\
\hline D. solivaga Birstein and Tchindonova, 1958 & $49 \mathrm{~N}$ & Kurile-Kamtchatka & bathypelagic & $500-640$ & 7 \\
\hline D. stenurus Murano, 1969 & $35 \mathrm{~N}-32 \mathrm{~N}$ & Japan & bathypelagic & $0 ?-2300$ & 11 \\
\hline D. tenella Birstein and Tchindonova, 1958 & $27 \mathrm{~N}$ & Japan & mesopelagic & & 7 \\
\hline D. thaumatops Tattersall, 1907 & $50 \mathrm{~N}-44 \mathrm{~N}$ & $\begin{array}{c}\text { N-Atlantic (Faroes to } \\
\text { Bay of Biscay) }\end{array}$ & - & $1000-1370$ & 3,4 \\
\hline D. corberai n. sp. & $41-37 N$ & $\begin{array}{c}\text { Mediterranean } \\
\text { (eastern and western) }\end{array}$ & suprabenthic & $358-1858$ & This study \\
\hline
\end{tabular}

Sea. A total of 130 specimens were collected in the eastern Mediterranean (Ionian Sea) and in the western Mediterranean (Balearic and Algerian Basins) at depths of 398-1859 m, suggesting that D. corberai is widely distributed on muddy bottoms of Mediterranean slopes (Table 1). All species of the genus Dactylamblyops live at considerable depths and in widely scattered parts of the world's oceans (Table $2)$. There are two species of the genus with a distribution close to that of the new species (NE Atlantic, Bay of Biscay): D. goniops and D. thaumatops (Tattersall and Tattersall, 1951; Nouvel and Lagardere, 1976). Both species have recently been collected at depths of 816-1062 m on the Iberian-Atlantic coasts (Frutos, pers. comm.). No other Dactylamblyops species was found there after intensive sampling at similar depths to those used in the deep Mediterranean. With the current state of knowledge $D$. corberai can be considered a Mediterranean endemism. In poorly sampled environments such as the deep sea endemicity may depend on the sampling effort performed (see Cartes et al., 2009). However, this does not seem to be the case of $D$. corberai due to the wide sampling area covered since the 1990s in the deep Mediterranean and neighbouring zones.

Dactylamblyops corberai $\mathrm{n}$. $\mathrm{sp}$. is the third dominant mysid at bathyal depths in the Ionian Sea (at 473-603 $\mathrm{m})$, after Boreomysis arctica and Calyptomma puritani (Madurell and Cartes, 2003). It occurred in 33.3\% of the samples taken in the Algerian basin (Cartes et al., 2003 ) at depths of 802-1594 m, where only B. arctica, C. puritani and Parerythrops lobiancoi were more abundant. In the Balearic Basin it occurred in $47.6 \%$ of the samples (Cartes and Sorbe, 1995), with the highest abundance found at 1253-1287 m depth. Thus, as the amphipod Autonoe catalaunica (Ruffo et al., 1999), this is a relatively abundant species in deep-Mediterranean assemblages. The discovery of $D$. corberai shows how scant our knowledge of the deep-sea fauna of the Mediterranean is: being a subdominant species, it was not collected until it was properly sampled using suprabenthic sledges during the study of deep-sea suprabenthos in the 1990s (Cartes et al., 1994).

Dactylamblyops corberai $\mathrm{n}$. sp. is a strictly suprabenthic (hyperbenthic) mysid; only one specimen was collected in the water column (at 5-52 m above the bottom over soundings of 632-634 m), while 83 specimens were collected with suprabenthic sledges at the sediment-water column interface $(0-1.5 \mathrm{~m}$ nearbottom water layer). In the Ionian Sea, where four daily cycles were performed, $90 \%$ of specimens were collected at night in the $2 \mathrm{~m}$ near-bottom water layer (i.e. the height at which the plankton net is attached to the upper part of the trawl's mouth. Accordingly, the new species, as described for the dominant mysid in the deep Mediterranean, Boreomysis arctica (Cartes and Maynou, 2001), may perform some nocturnal movements upward the water column although never or rarely completely leaving the benthic boundary layer (i.e. the water column layer located at $c a .0-50 \mathrm{~m}$ above the bottom ).

\section{Key to species of hodgsoni-group Dactylamblyops} modified from Ii (1964) and Murano (1981)

1. Rostrum triangular with acutely pointed apex.......... D. latisquamosa Illig, 1906

- Rostrum evenly rounded or triangular with rounded apex................................................................ 2

2. Rostrum evenly rounded...................................... 3

- Rostrum triangular with rounded apex ................... 4

3. Antennal scale subequal in length to the antennular peduncle...... D. hodgsoni Holt and Tattersall, 1906

- Antennal scale extending beyond distal margin of antennular peduncle....................... D. atlanticus Murano and Mauchline, 1999 
4. Antennal scale short, not extending beyond distal margin of antennular peduncle D. fervida Hansen, 1910

- Antennal scale long, extending beyond distal margin of third segment of antennular peduncle ....... 5

5. Ocular papilla short and thick, never extends to distal margin of eye; distal half of antennal scale reaching beyond antennular peduncle; telson triangular... D. stenurus Murano, 1969

- Ocular papilla long and slender, extending beyond distal margin of eye; distal 1/3 of antennal scale extends beyond antennular peduncle; telson linguiform 6

6. Ocular process projecting belong the cornea; telson armed with 28 setae; inner ventral margin of the uropod endopod with 1 setae D. murrayi Tattersall, 1939

- Ocular process projecting to the distal end of the cornea; telson armed with 15-16 setae; inner ventral margin of the uropod endopod with 3 setae D. corberai n. sp.

\section{ACKNOWLEDGEMENTS}

We express our gratitude to Dr. Jean Claude Sorbe (Station Biologique d'Arcachon, CNR, Bordeaux, France) for an initial diagnosis of the new species and to Mrs. T. Madurell (HCMR, Athens, Greece), who collected the specimens in the Ionian Sea. We also thank Dr. D. Jaume (IMEDEA, CSIC) for comments on some specimens revised.

\section{REFERENCES}

Anderson, G. - 2010. Mysida Classification, January 20, 2010. Available from http: //peracarida.usm.edu/MysidaTaxa.pdf (accessed 20 April 2010).

Birstein, J.A. and J.G. Tchindonova. - 1958. Glubocovodniie Mysidii severo zapadnoi ciasti Tihogo Okeana (The deep sea mysids of the northwest Pacific Ocean). Trudy Inst. Okean., 27: 258-355.

Cartes, J.E. and F. Maynou. - 2001. Trophodynamics of the deepwater suprabenthic mysid Boreomysis arctica in the Catalan Sea (western Mediterranean). Mar. Ecol. Prog. Ser., 211: 225-234.

Cartes, J.E. and J.C. Sorbe. - 1995. Deep-water mysids of the Catalan Sea: species composition, bathymetric and near bottom distribution. J. Mar. Biol. Ass. U. K., 75: 187-197.

Cartes, J.E., J.C. Sorbe and F. Sarda. - 1994. Spatial distribution of deep-sea decapods and euphausiids near the bottom in the Northwestern Mediterranean. J. Exp. Mar. Biol. Ecol., 179: 131-144.

Cartes, J.E., F. Maynou, B. Morales-Nin, E. Massutí and J. Moranta. - 2001. Trophic structure of a bathyal benthopelagic boundary layer community south of the Balearic Islands (southwestern Mediterranean). Mar. Ecol. Prog. Ser., 215: 23-35.

Cartes, J.E., D. Jaume and T. Madurell. - 2003. Local changes in the composition and community structure of suprabenthic peracarid crustaceans on the bathyal Mediterranean: influence of environmental factors. Mar. Biol., 143: 745-758.

Cartes, J.E., F. Maynou, E. Fanelli, C. Romano, V. Mamouridis and V. Papiol. - 2009. The distribution of megabenthic, invertebrate epifauna in the Balearic Basin (Western Mediterranean) between 400 and $2300 \mathrm{~m}$ : environmental gradients influencing assemblages composition and biomass trends. J. Sea Res., 66:
244-257.

Hansen, H.J. - 1910. The Schizopoda of the Siboga expedition. Siboga Exp., 37: 1-123.

Haworth, A. H. - 1825. A new binary arrangement of the brachyurous Crustacea. Phil. Mag. J., 65: 105-106.

Holt, E.W.L. and W.M. Tattersall. - 1906. Preliminary notice of the Schizopoda collected by H.M.S. "Discovery" in the Antarctic Region. Ann. Mag. Nat. Hist., (7)17: 1-11.

Ii, N. - 1964. Fauna Japonica. Mysidae (Crustacea). Biogeographical Society of Japan, Tokyo.

Illig, G. - 1906. Bericht über die neuen Schizopodengattungen und -arten der deutschen Tiefsee-Expedition 1898-1899. Zool. Anz., 30: 194-211.

Illig, G. - 1930. Die Schizopoden der deutschen Tiefsee-Expedition. In: Chun, C. (ed.), Wissenschaftliche Ergebnisse Deutschen Tiefsee-Expedition auf dem Dampfer "Valdivia" 18981899, vol. 22 pp. 397-625. Jena, Gustav Fischer.

Jaume, D., J.E. Cartes and G. A. Boxhall. - 2000. Shallow-water and not deep-sea as most plausible origin for cave-dwelling Paramisophria species (Copepoda: Calanoida: Arietellidae), with description of three new species from Mediterranean bathyal hyperbenthos and littoral caves. Cont. Zool., 68: 205-244.

Madurell, T. and J.E. Cartes. - 2003. Suprabenthic peracarid fauna collected at bathyal depths of the Ionian Sea (Eastern Mediterranean). Crustac. Int. J. Crustac. Res., 76(5): 611-624.

Mauchline, J. - 1980. The biology of mysids and euphausiids. Academic Press, London.

Murano, M. - 1969. Three new species of Mysidacea from Japan. Crustac. Int. J. Crustac. Res., 17: 207-219.

Murano, M. - 1981. Mysidacea from the central and western Pacific V. Genera Heteroerythrops, Meierythrops, Pleurerythrops, Gibberythrops, Illigiella, Dactylamblyops, Pseudamblyops, Paramblyops, Dactylerythrops and Nakazawaia (tribe Erythropini). Publ. Seto Mar. Biol. Lab., 26(4/6): 261-302.

Murano, M., and J. Mauchline. - 1999. Deep-sea mysids from the north Atlantic Ocean with description of four new species. Crustac. Int. J. Crustac. Res., 72(3): 273-295.

Nouvel, H., and J.P. Lagardère. - 1976. Les Mysidacés du talus continental du golfe de Gascogne I. Tribu des Erythropini (genre Erythrops excepté). Bull. Mus. Nat. Hist. Natur. 3, 414 (Zool. 291): $1243-1324$.

Ohlin, A. - 1901. Arctic Crustacea collected during the Swedish Arctic expeditions 1898, 1899 and 1900 under the direction of A.G. Nathorst and G. Kolthoff. II. Decapoda, Schizopoda. Bihang Kongl. Svenska Vet. Ak. Handl., 27(4): 1-91.

Ruffo, S., J.E. Cartes and J.C. Sorbe. - 1999. A new bathyal species of the genus Autonoe from the Catalan Sea (NW Mediterranean. (Crustacea: Amphipoda: Aoridae). Boll. Mus. Civ. Stor. Nat. Verona, 22: 21-30.

San Vicente, C. - 2010. Mysidaceans. In: M. Coll, C. Piroddi, J. Steenbeek, K. Kaschner, F. Ben Rais Lasram, et al. (2010), The Biodiversity of the Mediterranean Sea: Estimates, Patterns, and Threats. PLoS ONE, 5(8): e11842, Supporting information 2nd file: $247-275$

Tattersall, W.M. - 1907. Preliminary diagnoses of six new Mysidae from the west coast of Ireland. Ann. Mag. Nat. Hist., Series 7, 19: 106-118.

Tattersall, W.M. - 1939. The Euphausiacea and Mysidacea of the John Murray Expedition to the Indian Ocean. John Murray Exp. 1933-34. Scient. Rep., 5(8): 203-246.

Tattersall, W.M. - 1951. A review of the Mysidacea of the United States National Museum. Bull. U. S. Nat. Mus., 201: 1-292.

Tattersall, W. and O. Tattersall - 1951. The British Mysidacea. London, Ray Society.

Wittmann, K.J. - 1999. Global biodiversity in Mysidacea, with notes on the effects of human impact. In: F.R. Schram and J.C. von Vaupel Klein (eds.), Crustaceans and the Biodiversity Crisis, pp. 511-525, Brill, Leiden Boston, Köln.

Wittmann, K.J. - 2001. Centennial changes in the near-shore mysid fauna of the Gulf of Naples (Mediterranean Sea), with description of Heteromysis riedli sp. n. (Crustacea, Mysidacea). Mar. Ecol., 22: 85-110.

Scient. ed.: M. Alcaraz

Received April 30, 2010. Accepted November 25, 2010.

Published online April 11, 2011 